\title{
Model Pembelajaran Course Review Horay untuk Meningkatkan Pemahaman Konsep Bilangan 1-10
}

\section{(Course Review Horay Learning Model to Improve Children's Comprehension toward the Concept of Number 1-10)}

\author{
Darajat Rangkuti ${ }^{1}$, Darmina Eka Sari Rangkuti ${ }^{2}$ \\ ${ }^{12}$ Pendidikan Guru Pendidikan Anak Usia Dini, Universitas Muslim Nusantara Al-Washliyah \\ ${ }^{1}$ rangkutidarajat@gmail.com, 2darminachan66@gmail.com
}

\begin{tabular}{ccc}
\hline First received: & Revised: & Final Accepted: \\
07 July 2019 & 18 November 2019 & 22 December 2019 \\
\hline
\end{tabular}

\begin{abstract}
This experimental study aims to increase children's comprehension of the concepts of number 1-10 by implementing the Course Review Horay Learning Model. The research subjects were group A children in PAUD Tunas Harapan Medan. The understanding of number concepts was evaluated from pretest and posttest with the indicator is to comprehend the concept of number. The scores were analyzed statistically by using the paired-sample t-test. The students in the experimental class were taught by using the Course Review Horay Learning Model, while the control was taught conventionally. The results of the study show the experimental class data group differs from the form control class with a significant value is $0.86(p=0.05)$. The results of the study concluded that the Course Review Horray Learning Model can significantly improve children's ability to understand the concept of number 1-10.
\end{abstract}

Keywords: Course Learning Horay, The Concept of Number, Learning Model

\begin{abstract}
Abstrak
Penelitian eksperimental ini bertujuan untuk meningkatkan pemahaman anak-anak tentang konsep bilangan 1-10 dengan menerapkan model pembelajaran Course Learning Horay. Subjek penelitian adalah anak kelompok A di PAUD Tunas Harapan Medan. Pemahaman konsep angka diukur melalui prates dan pascates dengan indikator pemahaman konsep bilangan. Skor dianalisis secara statistik dengan menggunakan paired-sample t-test. Kelas eksperimen diajarkan dengan menggunakan Course Review Horay Learning Model, sedangkan kelas kontrol diajarkan secara konvensional. Hasil penelitian menunjukkan kelompok data kelas eksperimen berbeda dari kelas kontrol bentuk dengan nilai signifikan adalah $0,86(p=0,05)$. Hasil penelitian menyimpulkan bahwa model pembelajaran Course Review Horray secara signifikan dapat meningkatkan kemampuan anak untuk memahami konsep bilangan 1-10.
\end{abstract}

Kata Kunci: Course Learning Horay, Konsep Bilangan, Model Pembelajaran

\section{PENDAHULUAN}

Angka merupakan bagian dari hidup kita, setiap hari kita menemukan angka atau angka dimanapun dan kapanpun. Pemahaman konsep angka pada anak perlu diberikan sedini mungkin dengan menggunakan cara yang tepat. Karena konsep angka merupakan konsep yang sangat penting untuk dikuasai anak, yang akan menjadi dasar bagi penguasaan konsep selanjutnya. Dengan memahami konsep angka, anak dapat memahami 
konsep matematika yang lain. Harjanto (2011) menyatakan bahwa konsep angka adalah jumlah yang menunjukkan benda saat dihitung, untuk dapat mengetahuinya maka anak harus memahaminya.

Selain itu, Saleh (2009) bahwa konsep angka adalah konsep dan pemikiran manusia terhadap perhitungan banyaknya suatu benda misalnya setelah 1 ada 2 , setelah 2 ada 3 , setelah 3 ada 4 dan seterusnya. Senada dengan pendapat tersebut, M. Yazid Busthomi (2012) menjelaskan tentang konsep angka merupakan dasar matematika yang terdiri dari menghitung angka, hubungan 1 ke 1 menghitung jumlah, membandingkan serta mengenal simbol yang dihubungkan oleh jumlah benda.

Menurut Ahmad Susanto (2011) karakteristik pemahaman konsep angka anak usia 4-5 tahun atau kelompok TK A adalah sebagai berikut: 1) membilang sampai dengan sepuluh; 2) menyebutkan urutan angka 3) membuat urutan angka 110 dengan benda; 4) menghubungkan lambang angka dengan benda sampai 10; 5) membedakan dan membuat dua kumpulan benda yang tidak sama, yang sama jumlahnya, lebih sedikit, serta lebih banyak.

Trianto (2010) mengatakan bahwa salah satu tolak ukur peserta didik telah belajar dengan baik ialah jika peserta didik itu dapat mempelajari apa yang seharusnya dipelajari, sehingga indikator hasil yang diinginkan dapat dicapai oleh peserta didik. Akan tetapi, kenyataan di lapangan menunjukkan bahwa tidak semua peserta didik dapat mencapai hasil sesuai yang diharapkan seperti halnya yang terjadi pada anak-anak yang berada di TK Kelompok A PAUD Tunas Harapan Medan.

Proses pembelajaran yang kurang kondusif tersebut diindikasikan menjadi faktor penyebab rendahnya nilai hasil pembelajaranpeserta didik karena aktivitas peserta didik akan sangat berpengaruh terhadap hasil pembelajaran peserta didik.

Salah satu indikator tercapainya proses pembelajaran adalah dengan melihat hasil pembelajaran yang dicapai oleh peserta didik. Hasil pembelajaran merupakan cerminan tingkat keberhasilan atau pencapaian tujuan dari proses belajar yang telah dilaksanakan yang diakhiri dengan evaluasi

Membuat seluruh peserta didik berhasil dalam pelajaran yang diberikan hingga mendapatkan hasil pembelajaran yang baik dan mencapai standar ketuntasan bukanlah hal yang mudah karena setiap peserta didik memiliki tingkat pemahaman dan cara belajar yang berbeda.

Penentuan model pembelajaran yang akan digunakan senantiasa diawali dari situasi nyata dan keadaan peserta didik dalam kelas agar dapat meningkatkan hasil pembelajaran peserta didik sehingga tujuan pembelajaran yang bermakna dapat tercapai secara optimal. Salah satu model pembelajaran yang bisa diterapkan adalah model pembelajaran.

Pembelajaran tipe Course Review Horay dipilih dalam penelitian ini karena memiliki beberapa keunggulan di antaranya pembelajaran lebih menarik, medorong peserta didik untuk dapat terjun ke dalam situasi pembelajaran, pembelajarannya tidak monoton sehingga peserta didik lebih antusias, termotivasi, dan semangat belajar karena suasana belajar lebih menyenangkan, serta dapat melatih kerjasama dan komunikasi yang baik antar peserta didik.

Dengan melihat keunggulan dari model pembelajaran tipe Course Review Horay diharapkan dapat membuat peserta didik menjadi tertarik dan lebih bersemangat serta antusias dalam mengikuti pelajaran, dapat membimbing 
peserta didik untuk belajar lebih aktif lagi, dengan kondisi tersebut peserta didik lebih nyaman menikmati pelajaran dan tidak mudah bosan, maka peserta didik akan memahami materi pelajaran secara mendalam, sehingga dapat meningkatkan aktivitas dan pemahaman konsep angka peserta didik.

Sehubungan dengan hasil survei dan permasalahan yang telah dijelaskan dalam uraian tersebut di atas, maka peneliti tertarik untuk mengadakan penelitian dengan tujuan untuk meningkatkan pemahaman konsep angka 1-10 melalui impementasi model pembelajaran Course Review Horay.

Salah satu model pembelajaran yang dianggap tepat dan sesuai untuk meningkatkan aktivitas anak adalah pembelajaran Course Review Horay. Pembelajaran Course Review Horay dipilih karena model pembelajaran ini jarang diterapkan oleh guru di kelas. Selain itu, pada pembelajaran Course Review Horay anak diajarkan untuk bekerja sama dalam suatu kelompok, sehingga dengan sendirinya dapat memperbaiki hubungan sosial antara para peserta didik, mengembangkan keterampilanketerampilan proses kelompok (Louisell dan Descamps dalam Trianto, 2011).

\section{METODE}

Metode yang digunakan pada penelitian ini adalah penelitian quasi eksperimen dengan menggunakan rancangan pretest-posttest pada kelas eksperimen dan kelas kontrol. Variabel bebas adalah model pembelajaran Course Review Horay sedangkan variabel terikat adalah kemampuan pemahaman konsep angka 1-10. Subjek penelitian ini merupakan peserta didik PAUD Tunas Harapan Medan Tahun Pelajaran 2018/ 2019. Jumlah peserta didik yaitu 20 orang.

\section{HASIL TEMUAN}

Hasil pretest-posttest akan dianalisis menggunakan teknik statistik (uji t). Teknik ini dipilih karena subjek yang sama mengalami dua pengukuran, yaitu sebelum intervensi dengan pretest dan setelah intervensi dengan posttest. Penelitian ini dilaksanakan di PAUD Tunas Harapan yang terletak di, Kec. Patumbak Kab. Deli Serdang tahun 2018.

Hasil uji teknik statistik Paired simple $\mathrm{t}$ test menunjukkan bahwa t-hitung 5,744 dan nilai probabilitasnya 0,00, maka menunjukkan bahwa ada perbedaan skor antara sebelum dan sesudah implementasi model pembelajaran Course Review Horay. Perbedaan mean rata-rata adalah 4,0714 di mana mean setelah implementasi model pembelajaran Course Review Horay lebih tinggi. Dari uji $\mathrm{t}$ terbukti bahwa perbedaan yang terjadi tersebut cukup berarti menyatakan bahwa model pembelajaran Course Review Horay efektif dalam meningkatkan kemampuan pemahaman konsep angka 1-10 anak.

\section{PEMBAHASAN}

Berdasarkan pelaksanaan tindakan yang dilakukan peneliti proses pembelajaran dengan menerapkan model pembelajaran Course Review Horay berhasil membuat kemampuan pemahaman konsep angka 1-10 mengalami peningkatan. Adapun pembahasan hasil penelitian ini meliputi keberhasilan implementasi model pembelajaran Course Review Horay tidak terlepas dari strategi, teknik serta media yang digunakan.

Pembelajaran di PAUD menganut prinsip learning by playing. Pemahaman konsep angka yang merupakan pengembangan kognitif juga dapat di lakukan dengan prinsip tersebut: 
Sebagaimana hasil penelitian Sukmawarti (2015) yang menyimpulkan bahwa permainan matematika mempunyai pengaruh terhadap perkembangan kognitif anak PAUD. Kegiatan yang dapat di terapkan dalam pembelajaran antara lain Course Review Horay. Model Pembelajaran Course Review Horay merupakan model pembelajaran yang dapat menciptakan suasana kelas menjadi meriah dan menyenangkan karena setiap peserta didik yang dapat menjawab benar diwajibkan berteriak "hore!" atau yel-yel lainnya yang disukai. Model pembelajaran ini berusaha menguji pemahaman peserta didik dalam menjawab soal, dimana jawaban soal tersebut dituliskan pada kartu atau kotak yang telah dilengkapi nomor. Peserta didik atau kelompok yang memberi jawaban benar harus langsung berteriak "hore!" atau menyanyikan yel-yel kelompoknya.

Model ini juga membantu peserta didik untuk memahami konsep dengan baik melalui diskusi kelompok Huda (2013). Suherman (2002) menyatakan bahwa Course Review Horay adalah suatu model pembelajaran dengan menguji kemampuan pemahaman menggunakan kotak yang diisi dengan kartu dan tempat meletakkan jawaban serta tanda benar. Anak yang pertama mendapatkan tanda benar akan langsung berteriak horay. Kartu yang di letakkan tersebut dapat di buat dengan modifikasi angka gambar sesuai konsep angka.

Menurut Sugandi dalam Jusman (2012) model pembelajaran ini, disajikan dengan permainan yang menggunakan kartu berisi kotak yang dilengkapi dengan nomor soal dan peserta didik/kelompok yang pertama mendapatkan tanda benar berbentuk garis vertikal, horisontal, atau diagonal langsung berteriak "hore!" atau yel-yel lainnya. Sementara menurut
Siswanto dalam Jusman (2012) menjelaskan bahwa model pembelajaran Course Review Horay merupakan model pembelajaran yang mampu menciptakan suasana kelas menjadi meriah dan menyenangkan karena setiap peserta didik yang dapat menjawab benar maka peserta didik tersebut diwajibkan berteriak "hore!" atau yel-yel lainnya yang disukai.

Model Course Review Horay ini adalah suatu model yang bisa digunakan guru sehingga tercipta suasana pembelajaran yang lebih menyenangkan, dan peserta didik merasa lebih tertarik untuk belajar.

Tujuan dari model Course Review Horay antara lain sebagai berikut :

a. Meningkatkan aktivitas belajar anak dalam menyelesaikan pembelajaran

b. Melatih anak belajar secara aktif

c. Mengajarkan kepada anak agar mampu berinteraksi dengan sesama teman tanpa memilih
d. Mengatahui langkah-langkah model Course Review Horay khususnya pada pemahaman konsep angka.

Dengan demikian selain dapat meningatkan pemahaman konsep angka dengan menggunakan model Course Review Horay juga dapat meningkatkan aktivitas belajar anak, dimana penerapan model Course Review Horay ini membuat anak tidak merasa jenuh, dan menjadikan suasana belajar menjadi menyenangkan.

Aktivitas belajar peserta didik pada proses pembelajaran akan mempengaruhi hasil pembelajaran peserta didik. Hal tersebut membuktikan bahwa model Course Review Horay dapat meningkatkan hasil pembelajaran peserta didik. Selain itu model pembelajaran tipe ini dikenal 
sebagai model pembelajaran yang dapat membantu peserta didik mengingat kembali pelajaran dengan cara menyenangkan sehingga daya tangkap peserta didik dapat ditingkatkan.

Beberapa faktor yang menjadikan hasil pembelajaran anak meningkat adalah kekreatifan guru dalam menyajikan materi, pemberian ruang kepada anak untuk lebih aktif dalam pembelajaran dengan belajar kelompok, intensif dalam memotivasi peserta didik, kekreatifan guru dalam mengelola kelas menjadi kelas yang komunikatif bagi peserta didik, dan kekreatifan guru dalam memfariasi-kan model pembelajaran untuk peserta didik yang mempunyai kegiatan untuk aktif dalam pembelajaran.

Berdasarkan uraian tersebut, maka melalui penelitian tindakan kelas ini, dengan model pembelajaran Course Review Horay anak menjadi lebih aktif bertanya mengenai hal yang belum diketahui dan lebih aktif mengeluarkan pendapat pada saat proses pembelajaran, lebih antusias dan bergairah atau bersemangat dalam mengikuti pelajaran, serta saling melengkapi kekurangan anggota kelompoknya dalam memahami materi pelajaran, sehingga diharapkan dapat dijadikan acuan untuk guru dalam mengembangkan penelitian tindakan kelas dalam pembelajaran dikelas pada materi pelajaran ataupun pokok bahasan lainnya, guna membantu meningkatkan hasil pembelajaran peserta didik serta mengembangkan penelitian dibidang pendidikan.

\section{SIMPULAN}

Hasil penelitian ini menunjukkan bahwa implementasi model pembelajaran Course Review Horay dapat meningkatkan kemampuan pemahaman konsep angka 1-
10 anak. Hal ini terlihat dari analisa menggunakan teknik statistikuji $\mathrm{t}$ terlihat nilai signifikan lebih besar dari taraf signifikan 0,05 yaitu 0,86>0,05 sehingga hipotesis nol yang menyatakan tidak terdapat perbedaan yang signifikan antara peningkatan kemampuan pemahaman konsep bilangan 1-10 melalui pembelajaran Course Review Horay dengan pembelajaran secara konvensional ditolak. Dengan kata lain bahwa kelompok data kelas eksperimen dengan kelas kontrol memiliki peningkatan kemampuan pemahaman konsep bilangan 1-10 yang berbeda.

\section{DAFTAR PUSTAKA}

Susanto. A. (2011). Perkembangan Anak Usia Dini Pengantar dalam Berbagai Aspeknya. Jakarta: Kencana Perdana.

Djamarah, S. B. (2008). Psikologi Belajar. Jakarta: PT. Rineka Cipta

Harjanto. (2011). Pengertian Konsep Angka. Jakarta: Balai Pustaka

Huda, M. (2013). Cooperative Learning: Metode, Teknik, Struktur, dan Model Penerapan. Yogyakarta: Pustaka Belajar.

Saleh. (2009). Pengertian Angka. Jakarta: Rineka Cipta.

Siswanto, F. (2012). Model Pembelajaran Course Review Horay (CRH). Jurnal Kreatif Tadulako Online Vol. 5 No. 8 ISSN 2354-614X. tersedia:http://eduadventure.blogspot. com/2012/07/model-pembelajaran-crhcourse-review.html.

Sugandi. (2012). Peningkatan Hasil pembelajaranPeserta didik Melalui Penggunaan Model Course Review Horay Pada Mata Pelajaran IPA Kelas IV SD Inpres Sintuwu, Jurnal Kreatif Tadulako Online Vol. 5 No. 8 ISSN 
Model Pembelajaran Course ... - Darajat Rangkuti \& Darmina Eka Sari Rangkuti

2354-614X

http://download.portalgaruda.org

Suherman, E. (2002). “Model Belajar dan

Pembelajaran

Berorientasi

Kompetensi". dalam Jurnal

Pendidikan dan Budaya (2): 17-18.

Sukmawati. (2015). Penerapan Permainan

Matematika Terhadap Pengembangan

Kognitif Anak Usia Dini pada PAUD
Az-Zaitun Medan, Jurnal Serunai Matematika, VII (13): 69-75

Busthomi, M. Y. (2012). Panduan Lengkap

PAUD Melejitkan Potensi dan

Kecerdasan Anak Usia Dini. Jakarta: Citra Publishing.

Trianto. (2010). Mendesain Model Pembelajaran Inovatif-Progresif. Jakarta: Kencana. 